単結晶シリコンを用いたマイクロブリッジ

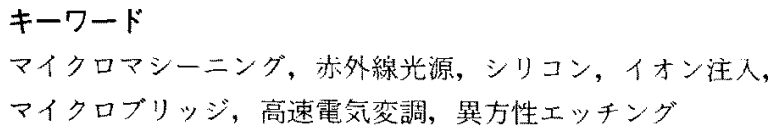

1.はじめに

マイクロマシーニングにより微小な三欣元構造で熱絶縁し たマイクロブリッジ光源 (1)-3),7)-8)や, イメージングディスプレ 14), マイクロヒータ 5)等, マイクロブリッジを必用し微小 な放射体をつくる鶖型素子の開発が活発に進められている。 マイクロフリッジ光源はジュール熱による発熱を利用し発光 する。理想的な黒体に近ければ分光放射分布はプランクの熱 幅射則に従い，図1の上5に500咳以上の温度で $4 \mu \mathrm{m}$ 上り 短波にピークを持つ。シリコン一つで広帯域の赤外線光源と なり，赤外吸収を利用した各種のガスの検知等多くの用途が 期待できる。また, マイクロブリッジの低熱容量化により高 速化が可能である。本稿では, マイクロマシーニングを用い てシリコンマイクロフリッジを形成し, 高速の電気変調を可 能とした小型赤外線光源の開発現状について紹介する。

\section{2. マイクロブリッジ光源の必要性}

赤外線ガス検知をはじめ赤外線計測の分野では, 広带城光 源としてヒータ光源が多く利用されている。フィラメント型

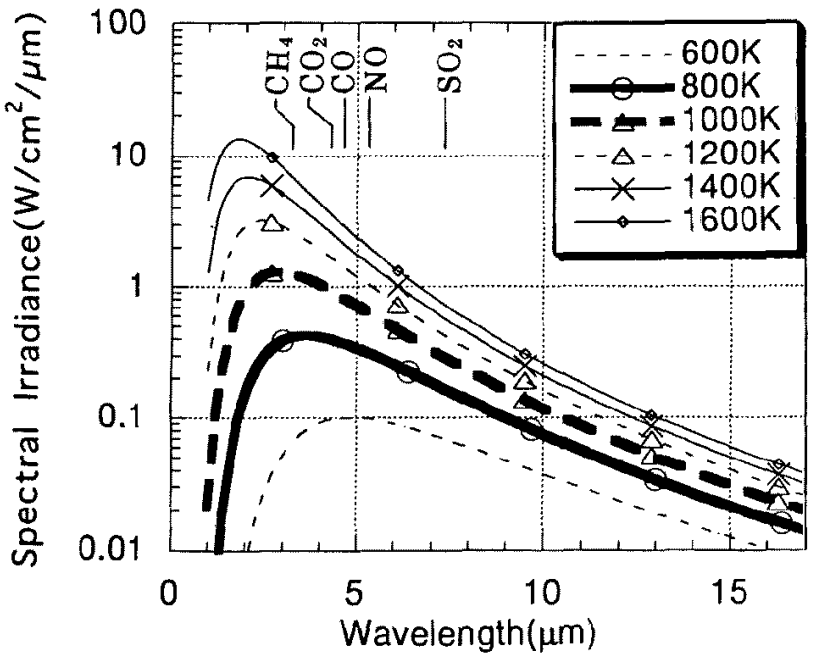

図 1 黒体の分光放射分布と代表的なガスの赤外吸収波長

Infrared Light Source Made of Single Crystal Silicon Microbridge. By Shiro Karasaura, Member, Seishiro Ohya, Hiroyasu Yuasa, Kenji Akimoto Non-member \& Setsuo Kodato Member (Kanagawa Industrial Technology Research Institute).

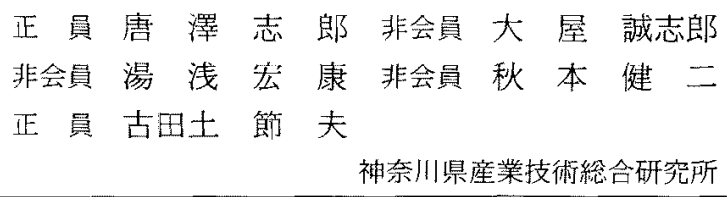

やグローバ光源が代表例である。これらの光源は熱容量が大 きいため, 䉓流を断続しての高速の電気変調動作は困難であ り，機械式のチョッパーで光路を遮り変調を行っている。し かし、慣性を利用して安定動作させるため駆動モータも大き くなり計测システムの小型化には適さない。

一方, PbCdS, PbSSe, PbSnSe, PbEuSeTe 等の IV-VI 族化 合物半導体レーサ(LD) は組成比と動作温度を変化させ特定 波長での最適化が可能である9)。しかし，異なった波長城で 利用しようとすると襩数のレーザヘッドを用意する必要があ る。またレーザ発振には冷凍器等による冷却が必要となる。 発光ダイオードでは InAsSbP P GaInAsSb の III-V 族 LED 光源が報告されている 10)。この素子は冷却は不用であるが， 現状で性高攽率化が課題である。これらの LD や LED 光源は 高速の電気変調動作が可能である。

発熱体に金属の厚膜抵抗体を用いたパルス赤外線光源 ${ }^{61}$

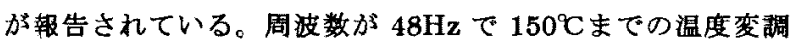
が可能である。しかし，基板の熱容量が大きく温度変調波形 はかなり变形しており，報告の周波数付近がこの光源の電気 変譯動作の上限になっている。

ヒータ光源や LD/LED，並びに厚膜光源には高速かつ広带 域の光源特性を得ることに限界がある。ヒータ型赤外線光源 に代わってマイクロマシーニングによりマイクロブリッジを 形成し，高速の電気変調動作により広带域の赤外楾光源を得 る試みについて以下に速べる。

\section{3、マイクロブリッジ光源の課題}

マイクロブリッジ光源の歴史は 1985 年の H.Guchel らによ るポリシリコンマイクロブリッジ光源にはじまる 1)。ポリシ リコン光源には, ポリシリコンのフィラメントを真空で封止

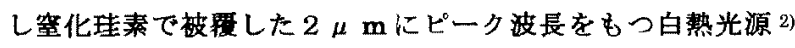
や酸化膜で被䖝したポリシリコン光源 3)が報告されている。 ポリシリコン光源では経時変化の解決が課題である ${ }^{3)}$ 。

一方，単結晶シリコンを用い赤外線イメージングディスプ レィへの忘用も陚みられている 4)。この応用では各素子から 放射される赤外線強度に大きな值は要求されず加熱温度は $270^{\circ}$ C と低い。発光部を小さくすれ淐高速電気変調に有利で あり，異方性エッチングの歩留まりも向上する。

ガス感知等の計测用光源の場合は，测定感度を上げるため $600^{\circ} \mathrm{C}$ 以上の高湜にし発光強度を增加させる必要がある。単 
結晶シリコンマイクロブリッジを用いた赤外線光源 7では $100 \mathrm{~Hz}$ で $700{ }^{\circ} \mathrm{C}$ 以上温度変調ができる。ここではディスプ レイとは逆に発光面糟を增加させて，全放射強度を上げる必 要がある。面積を大きくして高速に動作させるためブリッジ を薄くし熱容量を小さくする方法が必要となる。

\section{4. マイクロブリッジの村料選択}

高温・高速で使用するマイクロプリッジの材料選択には, 以下の点が要所となる。

1）熱サイクルに対し耐性がある：䚣流の断綍により発熱部 の温度は急敨に上昇, 下降する。動作温度は $600^{\circ} \mathrm{C}$ 以上と高 温である。このため, 高温で変質する材料は光源特性が変化 する。ポリシリコン光源では発熱部の伝導特性の経時変化が 報告されている ${ }^{3)}$ 。発熱体材料の候補としは高温で安定であ ることが必須である。異種材料などの接合構造は膨張係数の 差によるストレスが問題となる。

2 ）高熱伝導率である：立体㯨造では熱絶縁が向上し，発熱 部の温度の上昇速度を大きくできる。しかし，熱絶縁が良い ため温度の下降速度は粠造的に不利になる。この下降速度は 立体粠造を形成する材料の熱伝尊係数に大きく依存するため, 大きな熱伝導率をもつ材料が適している。我々が採用してい る単結晶シリコンは室温で金属である白金と同程度の熱伝導 率をもつ。熱伝導率が高い材料は，発光部内の均一な温度分 布の钼点からも望ましい。

3) 正の温度抵抗係数をもつ: 高速電気変調のため電流を高 速に断繶させる必要がある。負の温度係数の代表として半導 体があるが, 温度の増加に対して抵抗が低下し, 電流が増加 する。すると更に温度が上昇して部分的に高温になる。シリ コニット（SiC）の発熱体は負の温度抵抗俰数であるため, フィードバックを用いた電力制御回路が必要となる。このよ うな発熱体の電気制御は難しく発熱部を損稘しやすい。一方, 温度係数が正である発熱体は温度上昇に伴って抵抗が增加し， 自動的に負のフィードバックがかかり発熱部の過電流による 損倁が避けられる。特に素子が多数になった場合, 電圧制御 で駆動できるため，駆動回路の設計への負担が低減できる利 点をもつ。

4) 高放射率である：高温の発熱体から放射される赤外線 の放射量は材料の放射率により異なる。シリコンは非ドープ では放射率が低いがボロンをドープすると放射率が増大する ことが知られている。

\section{5. 単結晶シリコンマイクロブリッジの作製}

単結晶シリコンは熱サイクルに対する耐性において最も安 定性が期待できる材料である。ここでは光源から見た単結晶 シリコンマイクロブリッジの作製技術について述べる。フリ ッジの立体加工には, $10^{20} \mathrm{~cm}^{-3}$ の高浱度ボロンをドープした エッチングストッパ層の形成が必要となる 11)-13)。

高速の電気変調動作が不用な用途の光源には, ブリッジの 厳しい厚み制御は要求されず熱拡散法での作製が可能である。 熱拡散法ではマイクロヒータの作製が報告されている ${ }^{6)}$

高速の電気変調動作の光源には, 低熱容量化のため単結晶 シリコンブリッジの厚み制御が必要となる。1 $1 \mu \mathrm{m}$ 付近のフ
リッジ厚の制御のためには湌度と湌度プロファイルを独立に 制御可能なイオン注入技街が有攽である 7),8)。イオン注入技 術では熱拡散法(3 $\mu \mathrm{m}$ 厚 5) に比べ $1.5 \mu \mathrm{m}$ と薄いブリッ ジを形成できる。

異方性エッチングのエッチャントとして, ヒドラジン, $\mathrm{EDP}, \mathrm{KOH}$, アンモニアが報告されている。ブリッジの厚み 制御には不純物䈨度のレベルが重要となる。異方性エッチン グの不純物漼度依存性について EDP で詳細な報告がある ${ }^{11) 。 ~}$ $110^{\circ} \mathrm{C}$ の湜度において(100)面のエッチングレートはボロンの 不純物浱度が $10^{19} \mathrm{~cm}^{-3}$ 近くから減少しはじめ $2 \times 10^{20} \mathrm{~cm}^{-3}$ では じめの $1.4 \times 10^{-4}$ となる。アンモニアではこの值は $1.3 \times 10^{20} \mathrm{~cm}^{-3}$ で $1.25 \times 10^{-4}$ となる ${ }^{12)}$ 。この選択比により高湌 度ボロンはエッチングストッパーとなる。酸化膜をマスクと する時, 報告值 11)-13)で比較するとアンモニアに対するマスク のエッチングレートは $0.6 \AA /$ 分で最も小さい。発光面積を必 要とする赤外線光源のブリッジ形成には, 濃度レベル, 選択 比，マスクの耐性の点でアンモニアが有利と考えられる。

6. 単結晶シリコンマイクロブリッジ赤外線光源

赤外線光源としての詳細な特性を報告した論文は少ない。以 下では著者らが開発した単結晶シリコンマイクロフリッジ赤 外線光源 7),8)について述へる。

\section{1 特徽}

1）熱サイクルに対する耐性において最も安定性が期待され るモノリシックの単結晶シリコンから構成されている。

2)シリコンの熱伝導率は $1.56 \mathrm{~mW} / \mathrm{K}$ と良好であり, 温度下降 速度が大きい。

3)㳑度抵抗俰数は正であり, 電流に対し負のフィードバック がかかるため, 過電流による発熱部の損傷が避けられる。 4)金属転移レベルまで高浱度のボロンがドープされているた め, 放射率が非ドープシリコンよりも大きい。

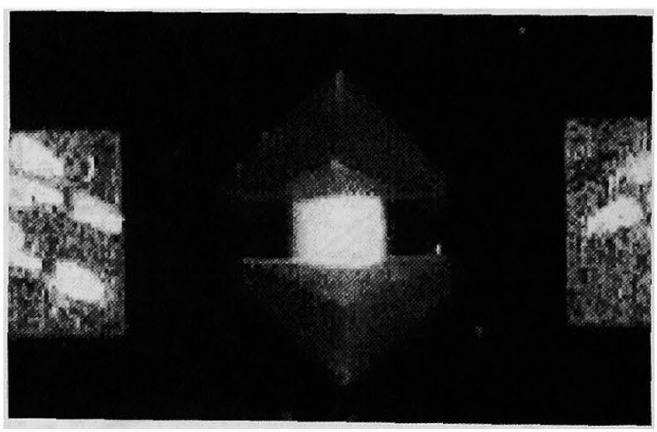

写真 1 発光中の単結晶シリコンマイクロブリッジ赤外線光源

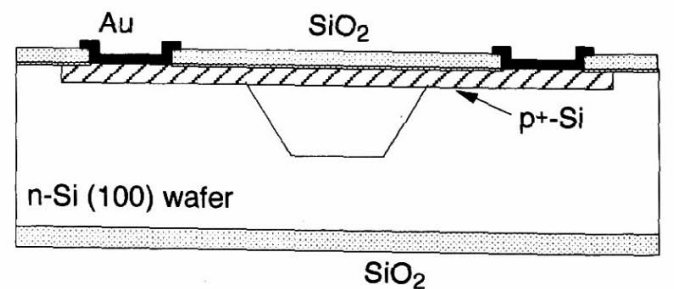

図 2 光源素子の断面構造 


\section{2 秦子拝造}

写真 1 に発光中の単結晶シリコンマイクロフリッジ赤外線

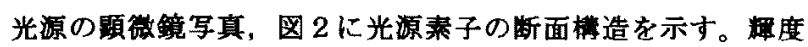
の高い放射領城の面積は 200×200 $\mu \mathrm{m}^{2}$, ブリッジサイズは $650 \times 200 \mu \mathrm{m}^{2}$ である。光源の発熱部分, 電極部分をイオン 注入により高濩度ボロンをドープし，これを異方性エッチン グのストッパーとして用いると同時に，発熟部をヒートシン ク部と熱絶縁したマイクロブリッジを形成する。異方性ェッ

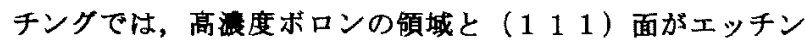
グがされにくく，ブリッジと橋梁下の側壁を（（llll）面で 囲まれた䏱が形成される。発熱部，電極部，ヒートシンク部 はモノリシックのシリコンにより構成されている。

\section{3 光源特性}

a)電気応答性： 単結晶シリコンマイクロブリッジ部の抵抗

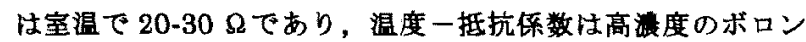
ドープシリコンのため金属的であり正になっている。このた め電压印加時に妵度が上昇するとともに，プリッジ部の抵 抗が増加し，流れる電流が急速に減少し温度が安定する。こ のように負のフィードバックがかかるため，简単な電瓜制御 のみで光源素子を㬓䙲できる。これにより温度一抵抗特性が 負の光源心必要な被雓な制御回路は不用となる。

b) 赤外線放射特性：InSb と $\mathrm{HgCdTe}$ 挨出器を用い分光放

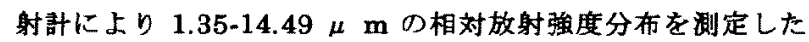
結果を図 3 に示す。500ㄷに加熱した高篮度ホロンドープシ リコンからの放射強度分布は $4 \mu \mathrm{m}$ 付近にピーク波辰をもつ。 c) 温度応答特性：素子の放射温度即定には，検出器に InSb を用いた影碝鏡型赤外線放射温度計が有动である。 $50 \mathrm{~Hz}$ 矩形波の電圧を入力した時の沮度の時間変化を図 4 に示寸。 温度は電圧周加時に急速に上昇して安定し, 電圧 off 時に急 速に下降する。温度上年時の光源素子の熱時定数は $1 \mathrm{msec}$ 以 下であり速い忘答性をもつ。 $100 \mathrm{~Hz}$ の正弦波電力の投入に 対する発愁部ピーク沮度は投入電力に比例し增加する。 $150 \mathrm{~mW}$ の投入電力だけで発熱部は $780^{\circ} \mathrm{Cになる。}$

d) 温度変調特性：投入電力周波数に対する温度变調の变化 を図 5 に示す。ここで入力電圧波形は正弦波であり，発熱部 の沮度変化の最高值と最低值の差を温度変調とした。周波数 が $100 \mathrm{~Hz}$ 以下では $700^{\circ} \mathrm{C}$ 以上の温度変誠がきでる。 $1 \mathrm{kHz}$ の温度変調は $100^{\circ} \mathrm{C}$ 以である。このように周波数の増加と ともに温度変調は娍少する。650x200 $\mu \mathrm{m}^{2}$ の素子では動作 周波数は $10 \mathrm{kHz}$ までであった。 $1 \mathrm{kHz}$ での沮度変調波形を図 6 に示す。金属㫗膜では温度変調波形の企みは大きいが，単 結晶シリコンブリッジ光源ではほとんど波形歪みは見られな W。

プリッジ部の面積が $650 \times 200 \mu \mathrm{m}^{2}$ の光源素子の性能は次 のとおり。1) $50 \mathrm{~Hz}$ の雨医矩形波印加時の熱時定数は $1 \mathrm{msec}$ 以下である。2）150mW の投入電力でマイクロブリッジは $780^{\circ} \mathrm{C}$ に加愁される。3） $100 \mathrm{~Hz}$ の電力周波数での温度変調 は $700^{\circ} \mathrm{C}$ 以上である。4) $1 \mathrm{kHz}$ の電力周波数での温度変調 は 100 咳以上である。5） $700 \mathrm{~mW}$ の投入電力でマイクロフ

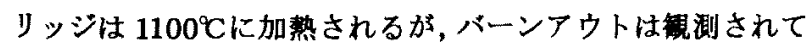

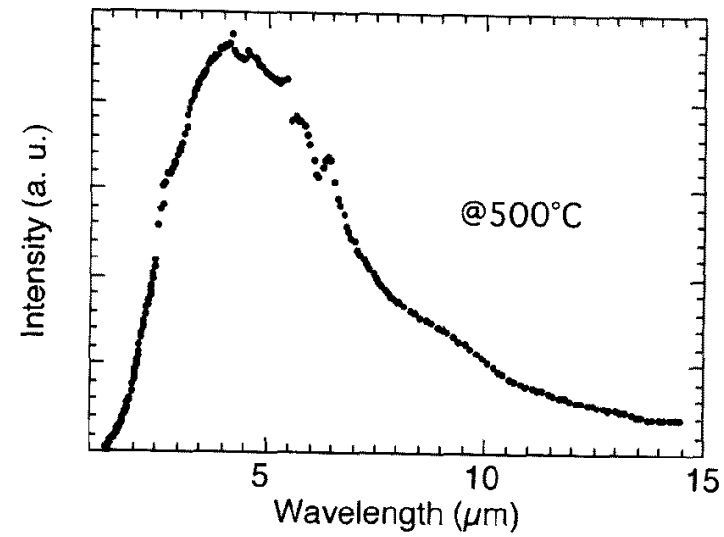

図 3 高流度ボロンドープシリコンの相対放射強度分布

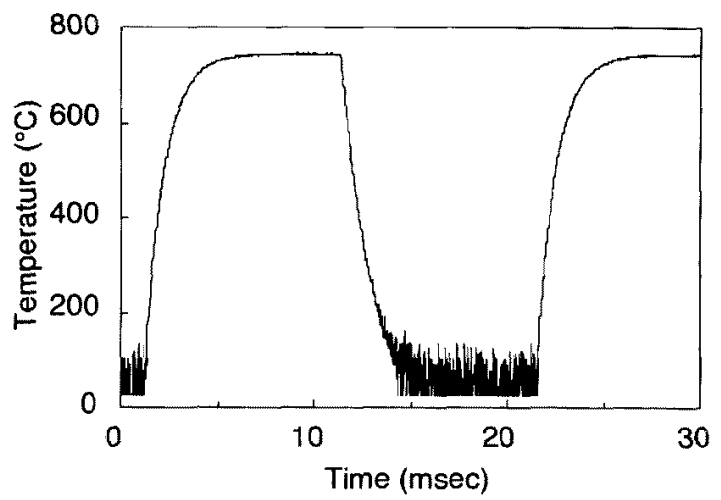

图 4 温度店答特性

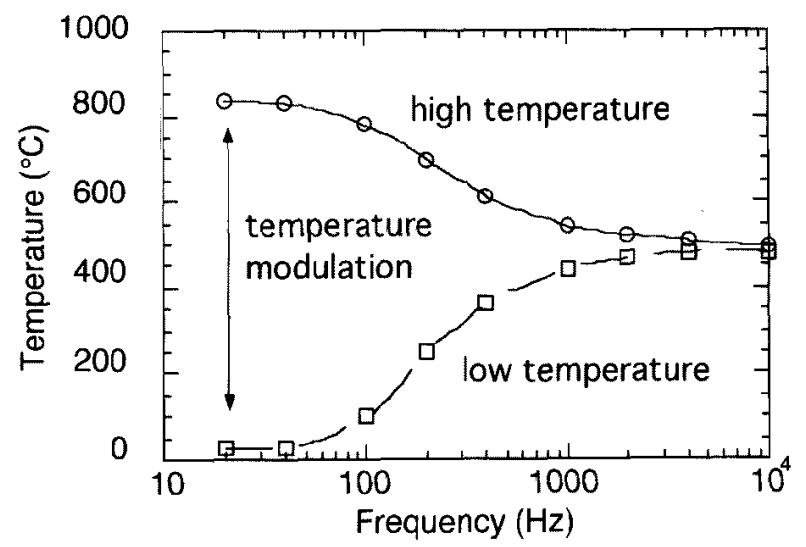

図 5 沮度变調愊の质波数俵存性

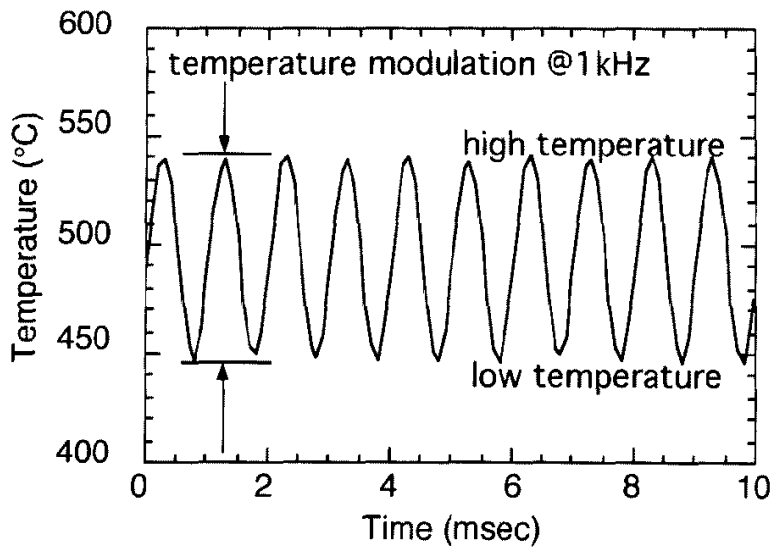

図 $61 \mathrm{kHz}$ での温度変調波形 
いない。面積が $365 \times 85 \mu \mathrm{m}^{2}$ の光源素子 ${ }^{8)}$ では 1) $200 \mathrm{~Hz}$ の電力周波数での温度変調は $700^{\circ} \mathrm{C}$ 以上である。2） $2.5 \mathrm{kHz}$ の電力周波数で温度変調は $100{ }^{\circ} \mathrm{C}$ 以上である。

7.おわりに

単結晶シリコン赤外線光源は, 高速かつ広帯域の光源特性 が得られる点で従来にない光源特性を与えている。また，駆 動電気信号波形による波形歪みの少ない温度変調が可能であ る。高速の電気変調を生かし機械駆動をなくすことによりカ ス検知器の光源機構部は数十分 1 の小型化が期待できる。

(平成 9 年 2 月 14 日受付)

\section{文 献}

1) H . Guckel and D. W. Burns, "Integrated transducers based on black body radiation from heated polysilicon filaments," Transducers'85, 364-366 (1985).

2) C.H.Mastrangelo and R.S.Muller, "Vacuum-sealed silicon micromachined incandescent light source, " Tech. Digest of International Electron Devices Meeting, 503-506 (1989).

3) M.Parameswaran, A.M.Robinson, D.L.Blackburn, M.Gaitan and J.Geist, "Micromachined thermal radiation emitter from a commercial CMOS process."

IEEE Electron Device Letters, 12, 57-59 (1991).

4)L.Burriesci and D.Keezer, "A dinamic RAM imaging display technology utilizing silicon blackbody emitters," SPIE, Vol.765, 112-122(1987).

5) M.Kimura and K.Komatsuzaki, "Microheater made of heavily boron doped single crystal silicon beam," Tech.Digest of the 11th Sensor Symposium, 169-172 (1992).

6) D. W. Knodle, P. Graham and J.O.Sams, "Optimization of a thick film resistor for use as a pulsed infrared emitter," SPIE Vol.1338, 102-110 (1990).

7) H.Yuasa, S.Ohya, K.Akimoto, S.Karasawa and S.Kodato, "Infrared light source made of heavily doped single crystal silicon microbridge," Tech. Digest of the 14th Sensor Symposium, 113-116 (1996). Trans. IEE of Japan, to be published.

8)H.Yuasa, S.Ohya, S.Karasawa, S.Kodato, and K. Akimoto,"Transient thermal analysis of micromachined silicon bridge," SPIE Vol.2880, 280-287 (1996).

9) H.Preier and R.Grisar, "Application of semiconductor radiation detectors and diode lasers for infrared spectroscopy," Measurement Vol.3, 153-160(1985).

10)Y.P.Yakovlev, A.N.Baranov, A.N.Imenkov, and M.P.Mikhailova, "Optoelectronic LED-photodiode pairs for moisture and gas sensors in the spectral range 1.8-4.8 $\mu \mathrm{m}$," SPIE Vol.1510, 120-127(1991).

11)N.F.Raley, Y.Sugiyama, and T.Van Duzer, "(100) silicon etch-rate dependence on boron concentration in ethylenediamine-pyrocatechol-water solutions," J. Electrochem. Soc. Vol.131, 161-171(1984).

12) U.Schnakenberg, W.Benecke and B.Loechel, " $\mathrm{NH}_{4} \mathrm{OH}$ based etchants for silicon micromachining," Sensors and Actuators, A21-23, 1031-1035(1990).

13) K.E.Petersen, "Silicon as a mechanical material," Proc. IEEE, 70, 420-457(1982).

唐浬志郎（正員） 1947 年 9 月 11 日生まれ。78 年筑波大学

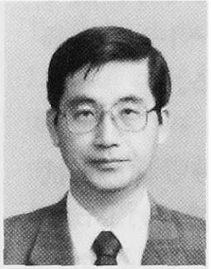
物理学専攻博士課程修了。理学博士。神奈川 県産業技術総合研究所勤務。光素子プロジェタ卜

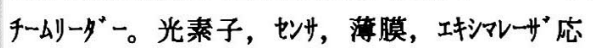
用に関する研究に従事。応用物理学会会員。 日本分光学会会員, 同会常務委員。

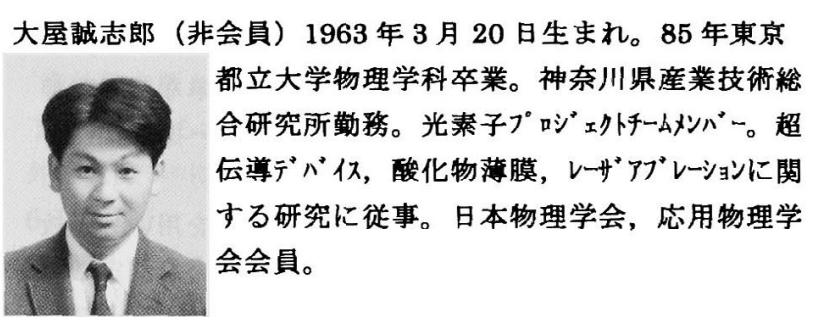

湯浅宏康 (非会員) 1967 年 10 月 16 日生まれ。90 年東京理

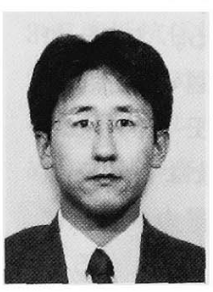
科大学物理学科卒業。神奈川県産業技術総合 研究所勤唀。光素子プロジェクトチームメンバー。マイタロ マシーシグに関する研究に従事。

秋本健二 (非会員) 1949 年 5 月 25 日生まれ。73 年東京理 科大学物理学科卒業。現在光明理化学工業

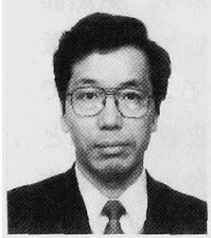
(株)勤務。神奈川県産業技術総合研究所協力 研究員。赤外線ガス検知システムに関する研究に 従事。

古田土節夫（正員）アンリツ（株）研究所勤務。工学博士。

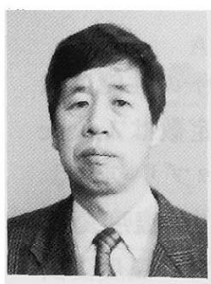
93-95 年室蔽工業大学客員教授。95-96 年神 奈川県産業技術総合研究所客員研究員。95-

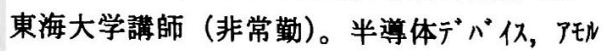
ファスセン情関する研究に従事。電子情報通信学 会, 応用物理学会, IEEE 会員。本会 $\mathrm{E}$ 部門 編集委員。おいしい水の識別センサ調査専門 委員会幹事。 